\title{
«ASUNTOS NEGROS». LAS AUTORIDADES ESPAÑOLAS FRENTE A LA ESCLAVITUD Y EL SERVILISMO EN LOS TERRITORIOS DEL SÁHARA OCCIDENTAL (1934-1957)'
}

\section{«Black Affairs». The Spanish authorities in the face of slavery and servility in the Western Sahara territories} (1934-1957)

\author{
JOSEP LLUÍS MATEO DIESTE \\ Universitat Autònoma de Barcelona \\ joseplluis.mateo@uab.cat
}

Cómo citar/Citation

Mateo Dieste, J. L. (2020)

"Asuntos negros». Las autoridades españolas frente a la esclavitud y el servilismo en los territorios del Sáhara Occidental (1934-1957).

Historia y Política, 44, 275-304 doi: https://doi.org/10.18042/hp.44.10

(Recepción: 04/07/2019; evaluación: 30/08/2019; aceptación: 15/11/2019; publicación: 27/11/2020)

Resumen

Este artículo analiza la política colonial española hacia la esclavitud y el servilismo en el Sáhara entre 1934 y 1957, con el objetivo de reconstruir las prácticas y el lenguaje administrativo de los oficiales espańoles acerca de una cuestión silenciada y de compleja definición como las formas extremas de dependencia. La fuente principal en que se basa el estudio son los documentos internos de la Administración colonial en el Sáhara español, que serán interpretados desde una doble perspectiva:

1 Este artículo es resultado del proyecto «Fronteras culturales en un mundo global» (FROGLOB), HAR2017-86776-P, financiado por el Ministerio de Ciencia, Innovación y Universidades. 
para reconstruir las relaciones de poder entre colonizadores y colonizados, y para descubrir los problemas de los colonizadores a la hora de definir y manejar las nociones de esclavitud. El resultado del análisis es que las autoridades españolas desarrollaron una paradójica política que prohibía formalmente el comercio de esclavos, pero que respetaba la institución del servilismo para no contravenir a muchos jefes tribales. A pesar de esta supuesta neutralidad, los oficiales españoles tuvieron que gestionar numerosos conflictos vinculados a la compraventa, la manumisión o la fuga de esclavos en un complejo espacio de frontera colonial, que reveló la agencia de los subalternos. Todo ello se produjo en un escenario repleto de tensiones e incertidumbres que mostraban la pugna por definir los propios fenómenos de esclavitud y servilismo en una época de cambios.

\title{
Palabras clave
}

Esclavitud; política colonial; Sáhara; manumisión; servilismo.

\begin{abstract}
This article analyzes Spanish colonial policy towards slavery and servility in the Sahara between 1934 and 1957, with the aim of reconstructing the practices and the administrative language of Spanish officials on a silenced and complexly defined issue such as extreme forms of dependence. The main source on which the study is based is the internal documents of the colonial administration in the Spanish Sahara, which will be interpreted from a double perspective: to reconstruct the power relations between the colonizers and the colonized, and to discover the problems of the colonizers in defining and handling the notions of slavery. The result of the analysis is that the Spanish authorities developed a paradoxical policy that formally prohibited the slave trade, but respected the institution of servility so as not to contravene many tribal chiefs. Despite this supposed neutrality, Spanish officials had to manage numerous conflicts related to the purchase and sale, manumission or escape of slaves in a complex colonial frontier space, which revealed the agency of the subalterns. All this took place in a scenario full of tensions and uncertainties that showed the struggle to define the very phenomena of slavery and servility in an era of change.
\end{abstract}

\section{Keywords}

Slavery; colonial policy; Sahara; manumission; servility. 


\section{SUMARIO}

I. INTRODUCCIÓN: DISCUTIENDO LA ESCLAVITUD. II. EL CONTEXTO SAHARAUI Y LA ESCLAVITUD EN LA OBRA DE CARO BAROJA. III. LOS OFICIALES COLONIALES Y EL DESIERTO POLITICO DE LA ESCLAVITUD: 1. «Esto de los morenos»: el lenguaje administrativo. 2. Instrucciones sobre el comercio de esclavos y gestión de fronteras. 3. Gestionando manumisiones. 4. Mediaciones en conflictos y huidas. IV. CONCLUSIONES: DESCONCIERTO COLONIAL. BIBLIOGRAFía.

\section{INTRODUCCIÓN: DISCUTIENDO LA ESCLAVITUD}

El siglo XXI está viendo la emergencia de compraventa de esclavos en escenarios de guerra y violencia como Sudán o la Libia de la era post-Gadafi. Las rutas migratorias transaharianas hacia Europa también recuerdan antiguas caravanas que transportaban esclavos desde el África occidental y central hacia el norte de África ${ }^{2}$. Para poder comprender mejor las raíces de estos fenómenos planteo un viaje al pasado colonial espańol más cercano, el relativo a la zona del Sáhara Occidental, todavía en conflicto político tras la fallida descolonización de 1975, basándome en fuentes primarias de la Administración colonial española. Este ejercicio reconstruye la ambigua gestión colonial de un fenómeno olvidado y su compleja definición: la esclavitud en el Sáhara, que al igual que en las zonas más septentrionales del Magreb tenía que ver con una forma extrema de servilismo. Pero la definición y acotación del propio fenómeno es problemática, de acuerdo con la literatura etnográfica, a la hora de marcar la frontera entre la esclavitud, las formas domésticas de servilismo y las "formas extremas de dependencia» ${ }^{3}$. Los oficiales coloniales se enfrentaron a esta ambigüedad del fenómeno y en sus documentos observaremos estos procesos de incertidumbre, así como el juego dialéctico que establecieron tanto con los propietarios como con algunos esclavos y libertos.

2 Seddon (2000) y Wright (2007).

3 Término propuesto por Georges Condominas en 1988. Villasante-de-Beauvais (2000b) y Botte (2007). 
La bisagra de este conflicto era el propio concepto de esclavitud o 'ubudiya , cuyo manejo centra los interrogantes de este estudio: ¿a qué se referían los funcionarios españoles y a qué se referían los propios saharauis, en su diversidad interna, cuando hablaban de esclavos, libertos, negros o protegidos, en castellano y en hasanía? La discusión sobre la esclavitud en esta situación colonial5 se debe situar en el debate más general sobre la esclavitud en el islam, que ha generado múltiples polémicas ${ }^{6}$. Este debate plantea si bajo el islam la esclavitud era más laxa en comparación con otros contextos, en especial en relación con el sistema de plantación americano. Pero cabe recordar que estos debates han devenido, también en la academia, en una batalla política para establecer definiciones, entre acusaciones de islamofobia e islamofilia. Este debate general es también un reflejo de tensiones recurrentes durante las diferentes situaciones coloniales. De hecho, el colonialismo europeo del siglo xix ostentaba la notable paradoja de perseguir el tráfico de humanos por medio del abolicionismo al tiempo que desplegaba la ocupación colonial en África, con sus formas de gestión de las poblaciones y la construcción de nuevas formas de servidumbre y dependencia respecto a los mercados mundiales y las metrópolis?

El impacto del colonialismo sobre las formas locales de esclavitud tampoco fue uniforme. En las regiones bajo influencia musulmana que rodeaban al Sáhara los colonizadores fueron poco claros a la hora de suprimir la esclavitud. Así, en el protectorado de Marruecos no se emitió ningún decreto que anulara el estatus de esclavo, más allá de una circular de 1922 en la zona francesa que prohibía el tráfico de esclavos ${ }^{8}$. En Mauritania, cuya estructura social se entrecruzaba con la sociedad saharaui, las autoridades francesas tampoco introdujeron reformas en este sentido y fue más bien la propia transformación de la sociedad, con la sedentarización, la generación de nuevos modos de subsistencia y jerarquía, y el movimiento de los harratin lo que impulsó la abolición de la esclavitud en diferentes momentos (1903, 1961 y 1980) $)^{9}$. La cuestión es que en esta región la esclavitud se fue transformando, e incluso después de las manumisiones el servilismo continuó existiendo bajo otras formas, y de hecho así está contemplado en la jurisprudencia islámica: amo y esclavo establecen vínculos de patronazgo aún

\footnotetext{
Chebel (2007).

Aquí emplearé estos términos prestados del trabajo fundacional de Balandier (1951).

6 Toledano (2007) y Zilfi (2010): 97-99.

7 Vergès (2001).

8 Botte (2010): 178-187.

$9 \quad$ Cheikh (1993) y Botte (2010): 198-199.
} 
después de la manumisión, definidos por el concepto de wala', que tiene continuidad entre generaciones ${ }^{10}$.

La falta clara de unas directrices para abolir la esclavitud en el Magreb se puede explicar por una calculada política colonial de aparente respeto del islam, motivada por el temor a generar malestar y resistencias políticas ${ }^{11}$. Los nuevos estudios coloniales apuestan por plantear, como mostraré en este trabajo, que el poder no se ejercía de modo unívoco, sino en un proceso dialéctico con las poblaciones locales. Como propone Stoler, los administradores coloniales también se regían por unas «ansiedades»" ${ }^{12}$, que en este caso podemos más bien tildar de incertidumbres y desconciertos por varias razones: la difícil gestión humana de un territorio inmenso sobre el que no se tenía un control efectivo real, ya que la ocupación inicial se limitó a los puntos de la costa, hasta la expedición del coronel Capaz a Ifni en 1934; y los vaivenes administrativos de la política colonial, aunque en el período aquí analizado se consolidó el africanismo franquista y su política de sueño imperial compensatorio ${ }^{13}$.

En la zona norte del protectorado español la política fue muy ambivalente y tampoco se prohibió oficialmente la esclavitud ${ }^{14}$. Ello también condicionó la actuación en el Sáhara, precisamente cuando el franquismo más impulsaba su retórica de la hermandad con el pueblo árabe ${ }^{15}$. Tras la muerte de Franco y el conflicto armado en el Sáhara se desarrolló en España una creciente saharofilia, contrapuesta a una maurofobia hacia Marruecos ${ }^{16}$. Este contexto hizo complicado investigar el tema de la esclavitud, tanto por razones políticas como por las propias dificultades de estudiar un fenómeno en transformación y unas poblaciones fragmentadas por el conflicto armado. Sin embargo, llama la atención que una cuestión nada baladí como la que aquí nos ocupa no haya sido abordada en profundidad, en contraste con la enorme literatura existente sobre la vecina Mauritania. Hubo que esperar hasta la publicación de De Dalmases en 2012 para tener una primera visión de conjunto de las imágenes espańolas sobre la esclavitud en el Sáhara ${ }^{17}$, desde que Caro Baroja dibujara con maestría la estructura social saharaui y el lugar

\footnotetext{
Ennaji (1994) y Botte (2007).

Harrison (2003).

Stoler (2010).

Nerín y Bosch (2001).

Mateo Dieste (2014).

González (2007).

López Bargados (2000).

17 Al libro De Dalmases (2012) hay que sumar su tesis doctoral con una amplísima bibliografía, en De Dalmases (2014).
} 
en ella de esclavos y libertos ${ }^{18}$, analizada en las etnografías que le siguieron sobre esta zona ${ }^{19}$, así como en los debates más explícitos sobre la esclavitud en Mauritania y el Sahel ${ }^{20}$.

En la línea de estos autores analizaré un corpus inédito de documentos emitidos por la Administración de los diferentes territorios bajo control español en el Sáhara y localizados en la sección de África del Archivo General de la Administración, en Alcalá de Henares. El material incluye informes, cartas, radiogramas y notas emitidas entre 1932 y 1953 en los diferentes territorios de Ifni, Cabo Juby, Saguía el Hamra y Río de Oro. El objeto de este artículo viene acotado por esta limitación temporal de los documentos, que se corresponde con el período comprendido aproximadamente entre la ocupación de Ifni por el coronel Capaz en 1934 y la transformación de los territorios del Sáhara en provincia española en 1958, tras la guerra de Ifni de 1957-58. Faltaría completar, pues, con fuentes primarias este período hasta el estallido del conflicto en 1975.

El enfoque para leer estos documentos parte de la mirada de autores como Ginzburg y la microhistoria ${ }^{21}$, para deducir entre líneas no solo las relaciones de poder entre colonizadores y colonizados, sino también la voz de los llamados subalternos, especialmente de mujeres esclavas o libertas huidas. Estas fuentes serán analizadas desde dos planos paralelos. En el primero, los documentos son un medio para acceder a datos sobre hechos y eventos, que nos permiten reconstruir la estructura social, las relaciones, las redes y los conflictos $^{22}$; estas tensiones constituyen una oportunidad excepcional para acercarse a la visión de los subordinados, particularmente en sus reclamaciones a las autoridades ${ }^{23}$. En un segundo plano, las fuentes devienen en un objeto de estudio en sí para conocer el modo en que fueron elaboradas, para quién fueron escritas, qué función desempeñaron en el engranaje burocrático y, finalmente, para analizar el lenguaje de la Administración con sus secretismos, incertidumbres y contradicciones ${ }^{24}$. Las palabras manejadas en aquellos papeles burocráticos, como «tráfico de negros», «esclavos» o «morenos» no

\footnotetext{
Caro Baroja (1990).

Caratini (1989) y López Bargados (2003).

Villasante-de-Beauvais (2000a) y López Bargados (2001).

Hernández Ciro (2016).

22 Comaroff y Comaroff (1992).

23 Toledano (1993) mostró en su estudio de la esclava circasiana Shemsigul las posibilidades de explotar fuentes policiales para rescatar testimonios que de otro modo no conoceríamos.

24 Stoler (2010).
} 
indicaban un reflejo de la realidad, sino que eran una contribución a conformar esa realidad a través de la política y el poder de definirla.

\section{EL CONTEXTO SAHARAUI Y LA ESCLAVITUD EN LA OBRA DE CARO BAROJA}

Los territorios comprendidos bajo el llamado Sáhara español eran muy extensos y fueron organizados en regiones administrativas artificiales y cambiantes, que recortaron la región con tiralíneas, dividiéndola en tres subzonas de norte a sur: Cabo Juby, Saguía el Hamra y Río de Oro. Pero las poblaciones nómadas locales se movían por otros parámetros, vinculados a lazos sociales y humanos más que territoriales, y a una praxis de subsistencia que seguía rutas específicas de pozos y puntos de intercambio, según el ciclo ecológico y temporal, en una región que se conocía como trab al-bidan, siendo este término bidan el que definía una identidad común de sus cabilas o tribus $^{25}$.

La presencia española en la región se había iniciado en tiempos de la Conferencia de Berlín, cuando la expedición española de Emilio Bonelli en 1884 dio paso a un protectorado nominal en la zona de Río de Oro entre Cabo Blanco y Cabo Bojador, aunque se limitó a puntos costeros sin poder efectivo $^{26}$. Con la firma del protectorado marroquí de 1912, España adquirió el territorio a la altura de Cabo Juby, denominado inicialmente como «Zona sur de Protectorado» y que no fue ocupado hasta 1916, aunque la presencia más incisiva no empezó hasta la misión del coronel Capaz en 1934. En 1946 esta zona fue agrupada junto a Saguía el Hamra y Río de Oro bajo una nueva entidad denominada África Occidental Española, hasta 1958.

La introducción de estas fronteras y una gestión territorial colonial entre puestos aislados transformó las estructuras sociales precoloniales, de manera que los grupos humanos organizados en qaba'il o tribus recompusieron sus estructuras y alianzas al quedar divididos entre los administradores franceses y los administradores españoles, generando lo que López Bargados denominó un «faccionalismo de frontera $»^{27}$. Es importante retener la importancia de este nuevo orden social para comprender lo que explicaré en las siguientes páginas, ya que la trayectoria de esclavizados, comerciantes, compradores o libertos se movió a través de estas nuevas fronteras

\footnotetext{
25 López Bargados (2003): 115-120.

26 Martínez Milán (2000).

27 López Bargados (2003): 469-475.
} 
coloniales, entre el sur de Marruecos, el Sáhara tutelado por Espańa y la zona gestionada por Francia. Y la Administración colonial se encontraba en el cruce de estos movimientos: puestos del sur que controlaban caravanas procedentes de Mauritania; puestos del norte que recibían notificaciones del protectorado francés sobre reclamaciones o ventas de camellos que eran utilizadas para comprar esclavos de nuevo en Mauritania, para venderlos en la zona espańola. De este modo, la frontera devenía una limes franqueada e instrumentalizada en un mundo cambiante que alteraba las formas previas de subsistencia, en las cuales esclavos y libertos desempeñaban labores de pastoreo, construcción de pozos, mano de obra, protección, trabajo doméstico y hasta funciones poéticas y religiosas ${ }^{28}$.

¿Pero cuál era la situación histórica de la esclavitud en aquellos territorios? Sin duda, un autor imprescindible para entender el estatus de libres, esclavos y libertos en el Sáhara es Julio Caro Baroja, quien hiciera un trabajo de campo relámpago en la zona auspiciado por las autoridades coloniales entre noviembre de 1952 y febrero de $1953^{29}$. En su etnografía Caro Baroja distinguía entre libres (ahrar), esclavos ('abid) y libertos (harratin). Y dentro de los esclavos había dos categorías:

- Los conocidos como náama, que nacen en la propia jaima y no se venden ${ }^{30}$. Solían darse vínculos de parentesco de leche entre estos esclavos y los libres, y aunque había blancas amamantando a esclavos, lo más frecuente era que «negras sean nodrizas de blancos»" ${ }^{31}$. Se esperaba que el trato hacia estos esclavos fuese más digno o que se les manumitiera si mostraban méritos o si podían comprar su libertad.

- Los tarbia, los que se compran y adquieren. Estas adquisiciones se hacían antiguamente a cambio de sal, por medio de comerciantes que traían los esclavos del sur ${ }^{32}$. Si leemos con atención esta distinción se podrán entender muchos de los ejemplos que seguirán, y sobre todo la confusión externa del primer tipo de esclavitud con el segundo, lo

28 Cheikh (1993): 184. Sobre la cuestión poética, véase el impresionante testimonio vivo de Mé Aicha, antigua khadm (sirvienta/esclava) del jeque Ma al-'Ayinin, en el documental de Dalila Ennadre La caravana de Mé Aïcha (2003).

29 Caro Baroja (1990): VII y Ortiz García (2006).

$30 \quad$ Nânma en Cheik (1993): 183.

31 Caro Baroja (1990): 48. Estos datos coinciden con las observaciones etnográficas de Ensel (1998) en los oasis del sur de Marruecos.

32 Sobre estos intercambios transaharianos que llegaban hasta el sur de Marruecos, véase Pascon (1984). 
cual también ha permitido invisibilizar al primer tipo entre las relaciones de proximidad y adopción.

En esta sociedad nómada, los «negros» (sudan) eran también mal vistos como en otras latitudes del Magreb o del mundo árabe ${ }^{33}$ y se les atribuía una mayor estupidez, lujuria y el no control de la palabra, además de provocar mal de ojo y otras aflicciones. Todo ello conducía a una normalización de su esclavitud, al considerar al esclavo como no persona o como un menor que requiere ser tutorizado y mantenido ${ }^{34}$.

Históricamente, las rutas y mercados de esclavos pasaban más bien por el nordeste sahariano, entre Marruecos y Níger. Las salinas de Yjil eran explotadas en el siglo XIX para comprar esclavos en el «Sudán» ${ }^{35}$. Cuando los franceses ocuparon Mauritania en 1904 este intercambio comercial de esclavos por sal se fue desmantelando, pero tal y como explica Caro Baroja no consiguieron terminar con él del todo. Refiere este autor que «hace cosa de diez años [ańos 1940] se registraron intentos de trata que tuvieron sus manifestaciones en nuestro territorio y que fueron suprimidos con toda eficacia, rescatándose de manos de mercaderes audaces algunos negros y negras que hoy viven en Smara y otras partes ${ }^{36}$. Estos registros son, casi con toda seguridad, los documentos inéditos que analizo más adelante.

Durante la etapa colonial se produjo una colisión de jurisdicciones y la situación de los esclavos no estaba exenta de problemas, como así lo reflejan las fugas durante aquel período: "Los negros dan lugar a varios tipos de problemas. A veces se fugan del hogar de sus amos, y la reclamación de éstos no es tan bien acogida por la justicia española como lo era por la indígena ${ }^{37}$. Esta tensión por las fugas dio lugar a reclamaciones, de las que se generaron expedientes diversos: «29-3-51. Un hombre muy rico reclama a un negro que se le escapó». Y al parecer, los fugados también caían en el peligro de volver a ser vendidos por terceros: «A veces hay individuos que quieren hacer trata de ellos, siendo sancionados (13-1-44. Individuo que quiso vender dos negras y fué detenido y enviado a Villa Cisneros)» ${ }^{38}$. Y "no faltan ocasiones en que un viejo pudiente compra negros de origen dudoso, y esto crea un conflicto grave

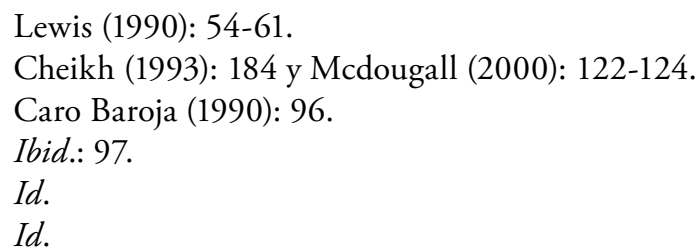


(26-11-48. Compra de una negra robada en Mauritania por un hombre de prestigio y ya anciano) ${ }^{39}$.

Los conflictos implicaban también tensiones familiares y matrimonios: «Un padre reclama contra su hijo por haberse casado con una negra (8-850)» ${ }^{40}$. Caro Baroja recogía también la situación de esclavos «libertos condicionales», que en realidad eran esclavos que serían liberados a la muerte del amo. En el siguiente caso se trataba de un grupo que vivía en una jaima: «Emboiarek. Este se halla en la situación del "liberto condicional” (mudabar), no puede ser vendido y cuando muera el sej quedará completamente libre» ${ }^{41}$. Y el antropólogo muestra el vínculo con otras personas negras emparentadas, que viven en jaimas o en pequeñas tiendas apartadas, llamadas benia, que se colocaban durante las horas de descanso. Los expedientes analizados por Caro Baroja son contemporáneos de los expuestos en las siguientes páginas.

\section{LOS OFICIALES COLONIALES Y EL DESIERTO POLITICO DE LA ESCLAVITUD}

\section{1. «ESTO DE LOS MORENOS»: EL LENGUAJE ADMINISTRATIVO}

El acceso a las fuentes primarias de la Administración española en los territorios del Sáhara nos permitirá contrastar la política colonial hacia esta cuestión, pero también puede dar luz sobre las condiciones de la esclavitud y el servilismo en la zona entre 1934 y 1957. Antes de proceder a este análisis es preciso detenerse en el lenguaje que la Administración española utilizó para dar nombre al fenómeno.

Los títulos que encabezan los documentos dedicados a los temas de esclavitud y servilismo contenían las siguientes expresiones: «trata de negros», «sobre negros», "comercio de negros», «esclavitud», "esclavos», "negros» o «asuntos negros». Y la información era archivada y clasificada en un «expediente de negros y esclavos». Para referirse a las personas epigrafiadas, en unas ocasiones se empleaba «esclavos», y en otras «negros» o «negras», y en algunos pocos casos «morenos». Los autores de los documentos fundían y confundían la cuestión del estatus con el aspecto físico, etiquetado por aquel entonces como «raza». Es decir, que identificaban esclavitud con negritud y viceversa. Aunque el africanismo franquista mezcló las nociones eugenésicas y cientistas

\footnotetext{
39 Id.

40 Id.

41 Ibid: 224.
} 
de la época con otras dimensiones religiosas en la noción de raza, ${ }^{42}$ en la época estudiada todavía estaba en boga un sistema de clasificación hegemónico y vulgarizado también entre los oficiales, que interpretaba la estructura social en términos raciales introducidos por la antropología física ${ }^{43}$.

Para describir el movimiento de esclavos los oficiales utilizaban las palabras "comercio», «trata» o «robo» («robo de dos negras»), y en una ocasión "venta de familiares de raza negra». Esta etiqueta ilustra a la perfección el entrecruce de las categorías en juego y las dificultades de definición del fenómeno, ya que la etiqueta de "familiares de raza negra» se estaba refiriendo a los adoptados, protegidos o "esclavos de la tienda». Esta fórmula de "familiares de raza negra», tan confusa como relevante, se mantuvo en el tiempo y permitía hasta cierto punto etiquetar el desconcierto moral frente al mantenimiento de formas extremas de servilismo. Según observa De Dalmases ${ }^{44}$, el censo español de 1974 contenía un llamativo eufemismo que no se puede pasar por alto: conocedores por aquel entonces de la existencia de esclavos o cuanto menos de poblaciones serviles, los autores del censo no incluyeron la categoría de «esclavos». Hubiera sido completamente contradictorio con las prohibiciones de esclavitud de un país, España, del que por aquel entonces el Sáhara formaba parte como provincia. Y así el censo introdujo términos como "hijos adoptivos y parientes pobres» ${ }^{45}$. De este modo se camuflaba en la unidad doméstica, que fue la unidad censal de base, la existencia de relaciones serviles o directamente originadas por compraventa de esclavos, y que en ese censo se elevaba a un total de 3081 personas, en una proporción similar de hombres y mujeres. Esta política de doble rasero y de tímida reforma se debió mantener desde la década de 1940 hasta el final de la presencia espańola, si nos atenemos a estos eufemismos del censo de 1974 que indican que el fenómeno quedó discretamente oculto.

Otra observación sobre la terminología es que los documentos oficiales restringían el término «indígena» para referirse a los bidan o a la población libre. De hecho, en los documentos de pase de frontera también refieren a la persona como «indígena» por defecto ${ }^{46}$. Pero llama la atención que al

42 Goode (2009).

43 Boëtsch y Ferrié (2000) y Villasante-de-Beauvais (2007).

44 De Dalmases (2012): 157. Sobre el papel clasificatorio de los censos, véase Angosto Fernández y Kradolfer (2012).

45 Pero podría tratarse de la adaptación de un concepto local. Bengoechea Tirado (2016: 52) menciona el término tinsafren, recogido por algunos autores, que se refiere a "parientes pobres».

46 (Ficha de pase) Sahara Español / Indígena / De la cabila / Fracción / Está autorizado a marchar a / Con objeto de / Llevando / Este pase es valedero hasta / Fecha y firma 
referirse al tráfico de personas no aparezca esta categoría de "persona», sino que se menciona en todos los documentos "tráfico de negros», asimilando negritud con esclavitud. A los bidan les llamaban indígenas. En cambio, a los esclavizados no los etiquetaban como «indígenas» — salvo en un caso-, sino como «negros», «esclavos» o «morenos». Esta forma de etiquetaje nos recuerda otros modos de clasificación, por razones bien distintas, en la zona norte. En el protectorado español los marroquíes musulmanes también eran etiquetados como «indígenas», mientras que los marroquíes judíos no eran etiquetados como «indígenas» sino como «hebreos» ${ }^{47}$, en una especie de extranjerización que se podría estar construyendo también en el caso de los «negros».

\section{INSTRUCCIONES SOBRE EL COMERCIO DE ESCLAVOS Y GESTIÓN DE FRONTERAS}

En enero de 1943 el delegado del gobierno de Ifni preguntó a Ángel Domenech Lafuente, delegado de sección, cuál era la situación de la esclavitud en el territorio. La consulta indicaba el grado de incertidumbre que sobrevolaba los despachos de la Administración colonial. La respuesta de Domenech Lafuente fue que "oficialmente, aquélla se halla abolida» ${ }^{48}$. Su argumentación indicaba la cautela de las autoridades frente al hecho de que la esclavitud estaba admitida por la religión islámica. Por consiguiente, solo iban a intervenir en caso de abusos o si los esclavos se presentaban a la autoridad para pedir ser liberados. En este sentido, no se emprendía una política activa para eliminar la esclavitud, sino para controlarla. Domenech reconocía que «ni en la Zona Norte de nuestro Protectorado en Marruecos se ha intentado hacer desaparecer esa condición social admitida en la religión musulmana». Pero era preciso no favorecer esa práctica y si algún esclavo se presentaba a una oficina española para denunciar abusos o reclamar su libertad, «se le ayudará con cautela y firmeza». La gran paradoja es que se debía permitir la posesión de esclavos mientras se les diera un trato humano.

Esta consulta entre altos mandos militares no era de extrañar, ya que en esa época todavía existían caravanas comerciales que atravesaban el territorio con

/ Debe presentarse en las oficinas de tránsito. Archivo General de la Administración (en adelante AGA), 81/13882.

47 Martín Corrales (2013): 98.

48 Carta de Ángel Domenech Lafuente, jefe de la Sección Política, al delegado del Gobierno de Ifni. Sidi Ifni, 29 de enero de 1943, AGA, 81/13882. 
personas destinadas al tráfico esclavista ${ }^{49}$. En marzo de 1943 se produjo en el puesto de Tichla, cerca de la frontera sur con la zona francesa, la compra de personas por parte de algunos bidan, incluidos militares o exmilitares saharauis del ejército colonial español. El mando del puesto de Tichla tenía constancia de los nombres de los compradores, entre ellos un antiguo sargento de un grupo nómada, un cabo de este grupo y un soldado, de la tribu de los Ulad Delim. Los vendedores eran comerciantes procedentes del sur de Marruecos que se dirigían a Mauritania para comprar esclavos y venderlos. Y las personas compradas eran hombres, pero también «una negra con dos nińos $»^{50}$, procedentes de la zona fronteriza de Mauritania. También tenemos noticia de la frecuencia de los traspasos y del tipo de bienes intercambiados. Uno de los hombres comprados fue vuelto a vender al cabo de dos meses «al cambio de dos camellos de tres ańos y medio y dos piezas de tela, a Ahmed uld Hamuadi», otro de los compradores presentes en el mismo puesto de Tichla. Ante estas compras, observaba la Delegación del Gobierno Político Militar, que habían procurado «restringir en lo posible este tráfico ilícito y en tres ocasiones se han enviado negros que procedían de Mauritania, por via marítima a Villa Cisneros para reintegrarlos a la zona de procedencia». El autor del informe era consciente de las dificultades de controlar ese tráfico y afirmaba que las medidas tomadas no evitarían por completo el tráfico, ya que los comerciantes podían encontrar otras rutas en la época de pastos.

Estas caravanas detectadas en 1943 y 1944 se componían de unos cincuenta camellos y transporte de ganado, comprado en la zona francesa limítrofe por comerciantes del sur de Marruecos. En una de ellas el cuidado del ganado iba a cargo de «seis negros ${ }^{51}$, quienes además de ser mano de obra podían ser vendidos y traspasados.

Otro de los circuitos recogidos en la documentación era el repetido por algunos bidan que adquirían esclavas para su unidad doméstica. El comprador acudía hacia el norte a la zona francesa de protectorado, vendía allí unos camellos a cambio de moneda francesa, regresaba al Sáhara y compraba una esclava con francos. Es el caso de Hamadi Uld Brahim Uld Lasen de los Erguibat, quien a su vuelta de Marruecos se dirigió al sur y compró a una joven de veinticinco ańos, llamada Selama ment Soliman, a su anterior propietario, ambos de Mauritania, cabila de Idab Lahsen. La joven, etiquetada como «del tipo negro

49 Cheikh (1993: 183) mantiene que el comercio, y no tanto la razia, fue el principal mecanismo de adquisición de esclavos.

50 Tráfico de esclavos entre Mauritania y nuestra zona. 1944, Gobierno Político Militar de Ifni Sahara (en adelante GPMIS). Zona Zaguia el Hamra. Aiún, 29 de septiembre de 1944, AGA, 81/13882.

$51 \quad I d$. 
de Guinea», fue comprada por 15000 francos. También sabemos que el oficial español habló con el comprador y con la chica. En este caso, el comprador «manifestó que no la quería para venderla, sino para tenerla en su jaima», $\mathrm{y}$ «la negra dijo que estaba muy contenta con su nuevo amo porque éste la trataba mucho mejor que el que tenía antes ${ }^{52}$. Se desprende, por tanto, que el oficial entendió que no existía abuso y no dio cuenta de cualquier otra medida.

En cambio, unos meses más tarde, en un caso similar el comprador fue detenido. Se trataba de Aomar Uld Enhamed Uld Azat, de los Rguibat. Vendió unos camellos en la zona francesa de Marruecos y con el dinero ganado se dirigió a Nuakchott, donde compró a «dos negras» de la cabila de Ulad Bu Sbaa a hombres de esta misma cabila. Se trataba de dos jóvenes, Salma Bentz Bilal, y otra joven llamada Baraquetu Mentz Mahamud, de 19 años, etiquetada como "pequeña, tipo de Guinea, color canela, en 50000 francos»" s $^{3}$.

Entre los condicionantes que conformaban estas prácticas de compraventa hay que incluir factores ecológicos, como las sequías de principios de la década de 1940, que alteraron las formas de subsistencia e impulsaron que diversos bidan de Río de Oro comerciaran con sus esclavos y protegidos. El siguiente caso demuestra la ambivalencia de la política espańola, muy condicionada por el temor a provocar el descontento local por un exceso de prohibiciones. En julio de 1942 se mandaron instrucciones sobre el tema tras observar que «estan vendiendo a sus familiares negros a nómadas pertenecientes a otras tribus de esta demarcación, especialmente a Izarguien» [zona norte de El Aaiún ${ }^{54}$. El oficial no se refería a esclavos, sino a «familiares negros»; es decir, que aun no siendo esclavos, se trataba de libertos o personas dependientes, al servicio del grupo de parentesco. En las instrucciones se aprecia claramente que el Gobierno colonial no se sentía cómodo con estas ventas de personas, pero en lugar de eliminarlas optó por acotarlas dentro de Río de Oro, «no permitiendose lo que pudieramos llamar exportacion ${ }^{55}$, para tener localizado el asunto. La práctica continuaba en abril de 1943, cuando un oficial de nomadeo informó que en el puesto de Bulimit «debido a la escasez de viveres se encuentra muy desarrollada la compra venta de personal de raza negra ${ }^{56}$.

52 GPMIS. Zona Zaguia el Hamra, Aiún, 13 de diciembre de 1944, AGA, 81/13882.

53 Expediente Esclavos. Compra de dos negras por el indígena Aomar Uld Enhamed Uld Azat. 1945, AGA, 81/13882.

54 GPMIS. Zona Rio de Oro. Secreto. Sobre venta de familiares de raza negra. Villa Cisneros, 23 de julio de 1942, AGA, 81/13882.

55 Id.

56 GPMIS. Zona Rio de Oro. Secreto. Sobre Boutilimit. Esclavitud. Dirigido al Jefe de la Sección Política del Gobierno Sidi Ifni-El Aiun, y al Delegado del Sahara. Villa 
El recordatorio recurrente de las prohibiciones a los oficiales indicaba la persistencia del fenómeno y las incertidumbres de aquellos. En septiembre de 1943 se reiteraba la obligación de detener las caravanas con esclavos: «Caso encontrar dentro nuestros Territorios caravanas conduciendo ESCLAVOS como objeto comercio, sea detenida; procúrense pruebas demuestren tal comercio; y deme cuenta para resolución " $^{57}$. Y en mayo de 1945 se repetían literalmente las instrucciones ya dadas por Domenech Lafuente a principios de 1943 sobre las personas sometidas «a tan triste condición», recordando que «está terminantemente prohibido dentro de los Territorios de este Gobierno la venta de esclavos ${ }^{58}$.

Es importante remarcar que los compradores de esclavos pronto tuvieron conocimiento de estas medidas y algunos se presentaron en las oficinas espańolas para evitar que les sancionaran, como Hamadi Uld Brahim Uld Lahsen de los Erguibat, quien argumentó que «sin saberlo habia comprado una negra, hacía un mes; que lo ponia en conocimiento para salvar la responsabilidad podia tener ${ }^{59}$.

A pesar de los controles rutinarios, el mando de Ifni era consciente de las dificultades de controlar un territorio tan amplio y sus fronteras, y desde Villa Cisneros se constataba que "el comercio de negros y camellos entre Mauritania y Marruecos se acentua cada dia mas. Indigenas de Uad Nun y otros puntos atraviesen nuestro Sahara con enormes sumas de francos, y entrando en Mauritania adquieren negros y camellos que luego son vendidos en Marrue$\cos { }^{60}$. Está claro que las tribus bidan aprovecharon estas fronteras a su favor, y que la competencia entre españoles y franceses contribuyó a definir este escenario. La Segunda Guerra Mundial acrecentó estas competencias y recelos. Pero la permisibilidad de las compras en el Sáhara francés se truncó a finales de 1946 cuando un teniente francés recorrió la zona de Bir Um Grain «recojiendo los negros que procedentes del Sudán han sido vendidos en estos ultimos tiempos», y deteniendo a un Erguibat de la zona española. ${ }^{61}$

Cisneros, 26 de abril de 1943, AGA, 81/13882.

57 GPMIS. Servicio Radiotelegráfico Militar. Radio para Aiun, Tantan y Villa Cisneros. De Ifni. El coronel gobernador, 5 de septiembre de 1944, AGA, 81/13882.

58 GPMIS. Telegrama postal. Circular. El coronel gobernador, Sidi Ifni, 21 de mayo de 1945, AGA, 81/13882.

59 GPMIS. Zona Saguia El Hamra. Sobre Esclavos. Aiún, 13 de diciembre de 1944, AGA, 81/14522. Existe otra ficha con la misma información del caso, con el epígrafe de «NEGROS».

60 Radiograma descifrado. De Ifni para Tantan y Aiun, 19 de agosto de 1944, AGA, $81 / 14522$.

61 GPMIS. Zona Saguia el Hamra. Semara, 20 de enero de 1947, AGA, 81/13882. 
Las instrucciones de 1943 se continuaban repitiendo en octubre de 1948 con la idea de no fomentar ni favorecer la esclavitud y de apoyar las quejas de los esclavos o de aquellos que expresaran "su deseo de pasar a la condición de horro $^{62}\left[\right.$ libre $»^{63}$. Se trataba de no interferir en los casos de esclavitud ya existentes, y de intervenir solo cuando los abusos fuesen flagrantes. Está claro que en todo momento había un cálculo y una prevención de evitar malentendidos entre la población local (no esclava) «llevando, poco a poco, el convencimiento de quiénes poseen esclavos, que ello es, solamente, una tolerancia nuestra, mientras a los esclavos se les trate correspondientemente y merecedor del ser humano. Si se encontraran dentro de nuestro territorio caravanas conduciendo esclavos, como objeto de comercio y se obtuviesen pruebas que lo demostrasen, se efectuará la detención de dichas caravanas» ${ }^{64}$.

Pero todo ello era reflejo también de las incertidumbres de la Administración. Las instrucciones del subgobernador eran un recordatorio en respuesta a un telegrama anterior del capitán de Smara que expresaba que «en esta no existen instrucciones sobre esta clase de indígenas» y no sabía cómo actuar. Además, las autoridades españolas estaban pendientes de los movimientos de las autoridades francesas, y solo a partir de 1953 parece que los franceses iniciaron una presión real para terminar con el tráfico de personas, encarcelando a quienes vendiesen esclavos, controlando las ventas entre tribus, así como la cesión y adopción de "familiares negros» ${ }^{65}$.

\section{GESTIONANDO MANUMISIONES}

Las instrucciones sobre la esclavitud fueron generales y sintéticas. Para valorar mejor su implementación he recogido en esta sección el modo en que los oficiales espańoles tuvieron que gestionar y enfrentarse a una realidad mucho más compleja y dinámica de lo que preveían dichas instrucciones. La

62 La palabra horro procede del árabe hurr, «libre», empleada también para referir a un liberto. El término fue incorporado al castellano para designar la figura del esclavo liberto, ya desde el siglo XVI y pasó con este mismo significado a las colonias americanas.

63 Carta reservada del Subgobernador del Sahara al Sr. Capitán Jefe de la Oficina destacada de Semara, 26 de octubre de 1948. Pero la información refiere las instrucciones emitidas ya el día 5 de abril de 1948, AGA, Caja 81/13882.

64 Id.

65 Sobre «Abolición de esclavitud en Mauritania», Delegación Gubernativa Zona Meridional del Sáhara, 1 de junio de 1953, AGA, 81/13882. 
población local, y especialmente los propios esclavos, esclavas o libertos se mostraron activos y acudieron a las oficinas espańolas para expresar sus reclamaciones, quejas, obtener manumisiones o dejar la resolución de sus conflictos en manos de la autoridad colonial, y enfrentarse a sus patrones. De este modo, la calculada neutralidad que pretendían los colonizadores no era posible en el cara a cara de las relaciones de poder entre aquellos grupos.

En la jurisprudencia islámica la manumisión tenía diversas posibilidades legales: que el propietario explicitara en su testamento que el esclavo quedaba libre el día de su defunción o que el esclavo pagara con dinero su propia libertad, por medio de trabajo. En la zona de Cabo Juby se produjo un caso del segundo tipo en 1932, que quedó registrado porque la manumisión terminó en conflicto. Este ejemplo demuestra además el uso estratégico de las fronteras por parte de los implicados. Faraye Ahmed ben Ali Biba era propietario de un esclavo llamado Meheyub. Este «adquirió su libertad según las leyes musulmanas en 160 duros españoles, entregando en el acto a su dueño 90 y quedándole, por lo tanto, deudor de $70{ }^{66}$. El liberto debía pagar esta cantidad con el salario que recibiría de un empleado francés de la Compañía Aeropostal en Cabo Juby. El francés se llamaba Joseph Vidal y, según observa el informe, puso al liberto a su servicio a cambio del mencionado salario hacia 1930. Dos ańos más tarde, y sin haber abonado la cantidad acordada, Vidal montó a Meheyub en el avión en dirección a Casablanca. El antiguo propietario, Faraye Ahmed, se desplazó a Rabat para reclamar el abono de la deuda. El delegado interino del alto comisario en Cabo Juby no tan sólo dejaba constancia de la información, sino que añadía, "por si considera conveniente interesar al citado empleado [Joseph Vidal] la mencionada suma de 70 duros que por causa de dicho señor no percibió el indígena Faraye». Es decir, que el administrador español parecía ponerse de parte del reclamante y de este modo reconocía la legalidad de la justicia cheránica. Este gesto que leemos en la carta indica que a principios de 1930 no se había establecido ni mucho menos una política de erradicación de la esclavitud.

En este mismo lugar, y muy poco antes, había tenido lugar un caso parecido con un ilustre de la literatura universal, el escritor y piloto Antoine de Saint-Exupéry, quien también a su paso por Cabo Juby liberó a un pastor esclavo llamado Bark. Y al igual que en el caso de Meheyub, el autor de $E l$ principito le preparó el viaje en avión a Marruecos, primero a Agadir, para ir

66 Notas sobre «Abolición esclavitud». Del coronel delegado interino al Alto Comisario. Delegación de la Alta Comisaría, Cabo Juby, 15 de julio de 1932, AGA, $81 / 11001$. 
luego a Marrakech ${ }^{67}$. Se desprende de este documento y de diversos testimonios recogidos por Dalmases, que no era nada extraña la práctica realizada por oficiales españoles de tomar a su servicio un antiguo esclavo, al que liberaban. Tras la Guerra Civil, el capitán de caballería Rodicio compró «dos negritos», Joselito y Josefina ${ }^{68}$. Más adelante muestro una manumisión oficial promovida por este mismo capitán en mayo de 1945. Por cierto, la práctica de poner nombres castellanos a los liberados no parece excepcional, ya que en uno de los documentos que he recogido se menciona a un cabo de regulares llamado Lahsem, al que se vincula una "negra liberta», llamada "EMBARCA BENTZ EL GER (Josefa)» ${ }^{69}$. En la selección de textos de Dalmases destaca el relato de José Meneses, un soldado valenciano que cumplía el servicio militar en 1970. En esta fecha tan tardía se encontraron con una caravana cerca de Smara, proveniente de Mauritania, y un hombre les ofreció comprar una niña de unos tres años. Al comentarlo a su mando, un teniente, le respondió que todo el mundo conocía el fenómeno, pero que tenían que "hacer la vista gorda». El grupo de soldados quedó tan impresionado que reunió la cantidad de dos mil pesetas para comprarla y liberarla. La niña fue enviada a Canarias al Patronato de Huérfanos.

Añadiré otro ejemplo inédito de liberación muy significativo, ya que en él se expresaban las motivaciones personales, además de las políticas, de un oficial español que decidió comprar a una niña para liberarla. En abril de 1944 pasó cerca de su oficina de Smara un comerciante de Bus-Sba, procedente del sur, "con 50 camellos y seis negros de viaje para Guilimin, desde luego todo autorizado mediante pase por la Oficina de Tichla». Y ańadía que:

Yo le compré una morenita pequeña, que me daba mucha pena por ser saladísima y además también por un poco de política con Said Uld Yumani, que a toda costa quería llevársela él y ante su insistencia viendo que si decía que era para mí se callaría, la compré dándole a continuación la libertad, pero ella no quiere separarse de mí. En esto de los morenos yo no se si se podrán pasar y vender en nuestra Zona, aún con pase de una Oficina, por lo cual ruego a $\mathrm{V}$ S.I., que me oriente respecto a esto para proceder en lo sucesivo ${ }^{70}$.

67 Estas memorias se encuentran en Tierra de Hombres, y debo el hallazgo al trabajo de De Dalmases (2012): 134-138.

68 Ibid.: 139-146.

69 Nota, s. f., AGA, 81/14522.

70 Comercio de negros. GPMIS. Zona Saguia el Hamra. Oficina de Smara, 1 de mayo de 1944, AGA, 81/14522. 
El hecho de que el oficial de Smara comprara una esclava, aunque fuese para liberarla, no entraba seguramente en los planes oficiales de la Administración central; de hecho, las instrucciones generales de 1943 quedaban más que en evidencia con este caso, ya que el oficial expresaba abiertamente sus dudas y preguntas sobre "esto de los morenos".

En el siguiente ejemplo de 1942 analizaremos las dificultades de gestión que tuvo que confrontar la Administración colonial frente a la incansable persistencia de una mujer esclavizada, Mbarka, por recuperar a su hija, Habiba, que puso en jaque el peso de las fronteras. Mbarka, madre de Habiba, había pertenecido como esclava a la familia Ben Derqawa de Dukkala, en la zona de protectorado francés. La familia Ben Derqawa casó a Mbarka con un capataz libre de Marrakech. Al poco murió el marido y el majzén la socorrió temporalmente, hasta que unos hombres le tendieron una trampa y la trasladaron a Uad Nun con la promesa de encontrar a sus primeros dueños. Pero fue llevada a Taki Uld Mami, un cargo del cheij Mohamed Lagadaf, y estuvo a su servicio. Más tarde fue a Tarfaya a buscar trabajo y conoció a un esclavo llamado Ramadan, de Brahim Uld Erguibi, con quien tuvo tres hijos. Ambos se acogieron a la posibilidad de manumisión pagando una cantidad de dinero, pero Brahim les engañó y no le dio la libertad. Además, su hija Habiba siguió en manos de los herederos de Taki Uld Mami. Entonces, la madre tomó la iniciativa de recuperar a su hija, a lo cual el cheij respondió que cheránicamente no era posible porque pertenecía a los herederos de Taki. La mujer fue a reclamar al oficial español de Sidi Ifni, quien escribió que era preciso "dar a esta mujer una palabra definitiva, evitando así se pase la vida en la puerta de la oficina de Saenz de Aranaz ${ }^{71}$. En efecto, Mbarka se le presentó y le rogó que escribiera al mando español en el Aiún "por conseguir que su hija Habiba [...] sea rescatada de su actual dueño; para lo cual ella está dispuesta a pagar lo preciso» ${ }^{72}$. El oficial de Ifni entendía que de ese interés de la madre no se podía beneficiar el propietario de Habiba y que no podía recibir ese dinero. Tras la petición de Mbarka, el oficial de Ifni pidió al oficial interventor de El Aiún que contactara con el cheij Mohamed Lagadaf, bajo cuya jurisdicción vivía el propietario de Habiba. El cheij respondió reconociendo la condición de Habiba («ella está esclava y su madre esclava»), pero argumentaba que no la podían dejar ir porque «ella la tiene la madre de Ahem Mami que está muy vieja y caduca con cerca de cien ańos y no puede levantarse, teniendo necesidad de la

71 Asunto: Habiba Met Dris Ben Laarbi. Intervención Local. Cabo Juby, 9 de julio de 1942, AGA, 81/13882.

72 Carta a Galo Bullón Díaz. GPMIS, Sidi Ifni, 17 de agosto de 1942, AGA, 81/13882. 
negra $»^{73}$. Tras la negativa del cheij aduciendo que la liberación atentaba contra la costumbre y la sharía, el oficial español «le hizo ver la conveniencia de que fuese liberada». Contradiciendo la opinión del cheij, una hija de la anciana, llamada Salma, se dirigió al puesto del Aiún y manifestó en la oficina que «Habiba era libre y que con ella vivía como una hija más. Finalmente, el cheij resolvió que Habiba fuera con su madre, pero que esta debía pagar una compensación de mil quinientas pesetas, el equivalente de tres camellas. El comandante adoptó una postura salomónica. Por un lado, el comandante escribía que con la declaración oral de Salma ya bastaba, aunque no se hubiese emitido ningún documento, porque había testigos orales. Y al mismo tiempo, reconocía que Mbarka había manifestado su disposición a pagar la libertad de su hija y aceptó que "podría enviar la madre ese ganado o su importe, para que se resolviera a satisfacción de todos». Al envío de esa carta, Habiba estaba camino del Aiún.

Si en el caso anterior observamos las dificultades de la Administración española para negociar entre las autoridades tribales y los sujetos de la esclavitud, en el siguiente ejemplo se aprecia la tensión entre las autoridades espańolas y francesas, y el uso instrumental de la frontera por parte de los bidan. En abril de 1944 tuvo lugar un incidente por la fuga de un esclavo que se quería presentar a una oficina espańola. Ello pone de manifiesto que por aquel entonces los esclavos ya eran conscientes de que si alcanzaban la oficina española tenían alguna oportunidad de ser liberados. Al mismo tiempo muestra el uso de la frontera por parte de las tribus, en este caso una rama de los Erguibat, que regresó a Mauritania para evitar a las autoridades espańolas:

Uno de los Erguibat Ulad Daud que se encontraban nomadeando en la zona de Imguegrerem, mandaron a uno de sus esclavos al pozo de Tiraclim para darle de beber al ganado. Que el negro intento venir a esta Oficina para que le dieran la libertad, que al enterarse los dueños, salieron en su persecucion, encontrandole en el camino, obligandole a volver no sin antes darle palizas. Que ante el temor de que se enterasen en esta Oficina, marcharon inmediatamente para la zona francesa ${ }^{74}$.

En esta nueva dinámica histórica las poblaciones locales tenían claro que el statu quo había cambiado. Unos eludían a los colonizadores, pero otros acudían a las oficinas españolas, conscientes de que los españoles habían

73 Carta del cheij Mohamed Lagadaf al comandante Galo Bullón, 8 de junio de 1942, AGA, 81/13882.

74 Esclavos. Aiún, 3 de abril de 1944, AGA, 81/13882. 
decidido poner coto a esta práctica. Un miembro de los Erguibat, fracción de Suad, llegó a la posición de Guelta procedente de Mauritania, donde había comprado a «la negra Aixa», de 35 años, de la cabila de Trarza, fracción de Ulad Deiman, a un hombre de la misma cabila por catorce mil francos. El comprador explicó que la había adquirido para comerciar con ella, pero que «al enterarse que no se permitia la venta de negros en la zona, queria poner en conocimiento que habia comprado él la negra, sin saber que no podia hacerlo, para que el Gobierno dispusiese lo que creyera oportuno" ${ }^{75}$. Las autoridades españolas dejaron a la mujer a «su poseedor en concepto de deposito", sin poder disponer de ella hasta que resolviesen los superiores. Aunque no figura la resolución final, en una nota manuscrita leemos que «el moro le pregunto a ella si queria venirse con el y le dijo que no le parecia mal, porque su amo la trataba muy mal».

No era la primera vez que la declaración de una mujer comprada era utilizada en este sentido para liberar formalmente a una esclava, pero dejándola igualmente bajo la tutoría del mismo comprador. No en balde, en casos de conflicto se procuraba la manumisión de la esclava, pero los responsables de la compra no recibían ningún tipo de castigo. Es el caso de Aicha, sobre la que se obligó a redactar un documento de libertad, pero las «perdidas sufridas por Abdu [su comprador] es el castigo impuesto ${ }^{76}$.

En similares circunstancias se produjo la liberación en febrero de 1945 de Baraquetu y Salma, cuyo caso hemos citado anteriormente, al apreciar el Grupo Nómada de Saquia el Hamra que un Erguibat había comprado dos esclavas en Nuakchott para venderlas, tras haber obtenido un dinero a cambio de camellos en el protectorado francés en Uad Nun. El comprador pagó cincuenta mil francos por Baraquetu, "de unos 19 ańos, pequeña, tipo de Guinea, color canela», y otros cincuenta mil por Salma, de 24 años, «estatura pequeña, tipo Guinea, color negro». Tras ser detenido, el comprador alegó que desconocía la prohibición y que «no se le puede prohibir vender las negras porque la justicia mora lo autoriza, hasta se atreve a decir que no le importaria vendieran a un hijo suyo, si es de justicia. [...] en prevision de que pueda vender a las negras se ordena las deje en este Puesto trabajando en concepto de libres hasta ulterior resolución $»^{77}$. Finalmente, el capitán adjunto de la delegación gubernativa del Sáhara, José Ruíz García, emitió un certificado de concesión de libertad a Salma:

75 Sobre Esclavos. GPMIS. Zona Saguia el Hamra. Aiún, 13 de diciembre de 1944, AGA, 81/13882.

76 GPMIS. Servicio Radiotelegráfico Militar. De Ifni a Aiun. Recibido el 21 de enero de 1945, AGA, 81/13882.

77 Esclavos. Oficina destacada de Smara, 26 de enero de 1945, AGA, 81/13882. 
CERTIFICO: Que en esta fecha se le concede a la musulmana negra SALMA MENT BILAL U. MESAUD, de la cabila de Ulad Bu Sbaa, fracción de Edmuisat, que habia traido a Zona Española para su venta el musulman Aomar Uld Emnamed Uld Azat, de la cabila de Erguiat, fracción de Suaad Ulad Bu Said; haciendo constar que se procede así en cumplimiento de lo dispuesto por el Excmo. Señor Gobernador del Territorio en orden telegrafica número cincuenta y dos de trece del actual ${ }^{78}$.

Pero como en otros casos, la libertad de las mujeres quedaba a merced de nuevos protectores, que en este caso fueron dos oficiales saharauis de las tropas coloniales: «Barqueto trabajando de criada del sargento Abdala. Salma trabajando de criada con el sargento del Grupo Muley Aomar»" ${ }^{79}$.

En mayo de ese mismo año se dio cuenta de otra manumisión promovida por la autoridad española. Interesa destacar de este caso que, desafiando las formas existentes de liberación, que eran monopolio de adules (notarios) y de la justicia islámica, el documento de libertad, traducido al hasanía, debía ser refrendado por la firma del capitán jefe de Smara, Argimino Rodicio, con el visto bueno del comandante delegado. ${ }^{80}$ La mujer liberada, Embarka, fue puesta al servicio doméstico del escribiente saharaui de la oficina, recibiendo de él cincuenta pesetas, ropa y comida.

\section{MEDIACIONES EN CONFLICTOS Y HUIDAS}

En el año 1948 se produjo un incremento de mediaciones de las oficinas españolas en asuntos de esclavos y protegidos, sobre todo vinculados a robos y fugas. De entre estas, la más llamativa es la de Embarek. Cuando leí en la etnografía de Caro Baroja sobre el Sáhara que algunos esclavos huidos cortaban parte de la oreja de un niño o de una yegua para pedir la protección a un nuevo dueño, me parecía una praxis probablemente exagerada por la literatura colonial ${ }^{81}$. Pero un documento demuestra la pervivencia del método en

78 Certificado de liberación. Don José Ruíz García, capitán adjunto de la Delegación Gubernativa del Sahara, Aiún, 15 de febrero de 1945, AGA, 81/13882.

79 Nota manuscrita, 16 de febrero de 1945, AGA, 81/13882.

80 Carta de Argimiro Rodicio González, capitán jefe de la Oficina al comandante delegado del Sáhara español (Aiun). GPMIS. Smara, 19 de mayo de 1945, AGA, $81 / 13882$.

81 En la sociedad saharaui los esclavos también eran acusados en algunas ocasiones de «desangrar a la gente con su mirada y efectuar otros actos de carácter maligno» (Caro 
1948, año en que un esclavo, escapando de la violencia a la que era sometido, se abalanzó sobre un niño creyendo que le estaban acorralando para devolverle a su dueño. Según describe el padre del niño, «con una piedra, le cortó parte su oreja, para evitar con ello, que si le daban alcance los que el negro creia eran sus dueños, éstos, no pudieron hacerle nada ${ }^{82}$. Pero el esclavo huido se enfrentó a unos nuevos tiempos en los que ese ritual ya obedecía a otras reglas del juego. El padre afrentado se negó a aceptar al esclavo (no sabemos si por otra razón o porque sabía de la prohibición de adquirir esclavos) y el esclavo fue puesto en la cárcel hasta resolverse su caso. Mbarek era propiedad de Mohammed, de la cabila de Ulad Tidrarin. En el careo con los oficiales declaró que su amo "lo maltrataba en extremo como lo prueba el que hace unos cinco meses le produjo una deformacion en el dorso de la muñeca izquierda" y que el hijo de aquel también le dejaba sin comida. Y que en su huida «le cortó [a Mahmud] la parte superior de la oreja derecha, con lo cual, quiso demostrar su acatamiento y deseo de pasar a la propiedad del padre del niño». En el dossier de esclavos se incluían unas «Notas sobre esclavitud» que daban cuenta de esta práctica y de la responsabilidad del dueño para responder de los actos delictivos de su esclavo. En el caso del corte de la oreja por parte de un esclavo maltratado que hubiese huido de la jaima, el dueño debía pagar los dańos ocasionados por el "negro» y en caso de no hacerlo perdía sus derechos sobre el esclavo, que pasaba a ser propiedad del receptor del daño ${ }^{83}$.

Una de los interrogantes que atraviesa esta investigación tiene que ver con las concepciones de esclavitud de españoles y saharauis en esta situación colonial. El servilismo formaba parte hasta tal punto del sentido común local, que la idea de protegido no estaba claramente distinguida de la de esclavo. En el siguiente caso estas nociones se ponen a prueba, así como su poder performativo. Emboiarec se presentó a la oficina de El Aiún en junio de 1948 huyendo de su amo, pero ya lo había hecho en 1941, cuando le acusaba de no darle comida ni ropa ${ }^{84}$. El caso es particularmente revelador de estas nociones

Baroja, 1990: 45). Esta acusación de «chupar sangre» (sellala) recaía en aquellos grupos de la sociedad considerados como marginales o fuera del islam, entre ellos los esclavos, especialmente mujeres, lo cual era todo un reflejo de la desigualdad estatutaria (Pettigrew, 2016: 422-423).

82 Carta del capitán adjunto al comandante subgobernador de Smara. Gobierno del África Occidental Española (en adelante GAOE). Subgobierno del Sahara. Aiún, 12 de marzo de 1948, AGA, 81/13882.

83 Notas sobre esclavitud, s.f., AGA, 81/13882.

84 Carta del capitán adjunto al comandante subgobernador del Sahara. GAOE. Subgobierno del Sahara. Aiún, 26 de junio de 1948, AGA, 81/13882. 
en juego, porque el «protector» amenazó al oficial español afirmando que si los espańoles empezaban a dejar escapar a los protegidos, la mayoría de ellos huirían de las tribus. Aquí se observa un cambio de vocabulario, ya que no se mencionan esclavos sino protegidos, aunque no queda claro si se está refiriendo a libertos. La noción de protegido discutida entre el amo y el oficial estaba siendo redefinida: este último le comentó que la protección era una tolerancia del Gobierno, dando a entender que debería estar prohibida; y el otro insistía en mantener sus derechos sobre el protegido y que se le obligara a volver con él. Se trataba de una lucha de poder entre diferentes «sentidos comunes $^{85}$.

En octubre de 1948 Um el Barca se presentó a la oficina de Smara para pedir protección de las agresiones de su amo. La central de Tan-Tan dio la razón a la mujer reclamante y desestimó las protestas del dueño. Como en otros casos, la intervención de la Administración colonial estaba motivada por la existencia de violencia y no tanto por la situación de esclavitud en sí, que quedó demostrada por los declarantes. Um el Barca provenía del Marruecos francés, tras ser agredida por Ahmed, «de Izarguien, Ait Said [zona española del Sáhara], que se decia su "dueño" a consecuencia de cuyos maltratos habia tenido que ser hospitalizada dos dias en Aiun del Dra ${ }^{86}$. Sobre los maltratos declaró que «durante todo el tiempo que ha estado con él, "sólo le ha pegado dos veces" pero no últimamente». Y como Ahmed no presentó documento alguno de boda, la autoridad española decidió alejar a Um el Barca a Tarfaya, «con socorro en metálico, hasta tanto que ésta encuentre medios de vida o de trabajo» ${ }^{87}$.

El poder de las etiquetas era tan influyente que el destino y posición social de una persona podía depender de estos sistemas de clasificación definidos por las Administraciones. Fatma ment Samba uld Brahim, y Fuinina ment Maiec uld Cauri se presentaron a la oficina de El Aaiún en noviembre de 1948. Procedían de la cabila de El Hayech, en zona francesa. Habían sido robadas, y tras pasar por diversos vendedores fueron introducidas en zona española por unos Erguibat de la zona francesa. Fatma fue vendida por el precio de «dos camellas con su cria, tres camelas preñadas, cuatro de dos años y doscientas veinticinco pesetas» ${ }^{88}$. Y Fuinina por el precio de «un camello

\footnotetext{
85 Keesing (1987).

86 Um el Barca mentz Emboiric uld sid Ahmed, «morena» de los Ahl Chej Ahmeduch U Soliman (Mauritania). GAOE. Sahara Español. Zona Saguia el Hamra. Nota procedente de Central de Tan Tan. Aiún, 20 de octubre de 1948, AGA, 81/14522.

87 Id.

88 Robo dos negras en la Mauritania. GAOE. Sahara Español. Zona Saguia el Hamra. Aiún, 24 de noviembre de 1948, AGA, 81/13882.
} 
macho de 10 años, cuatro asuasil, cuatro Eydaa de unos cuatro ańos y un Hag de dos años». Durante las declaraciones de las dos mujeres se produjo una contradicción con los documentos enviados por los franceses, que atribuían la propiedad a Chej Uld Lembaret, pero ellas negaron tal vínculo: «Éste fué llamado a la Oficina en presencia de sus protegidas y delante de él, ambas manifestaron no ser su dueño; que solamente lo conocen como familiar de ellos [los verdaderos dueńos].» Obsérvese el vocabulario empleado por las diferentes partes del conflicto. El relato del oficial español presentaba a las mujeres como "protegidas» y ellas utilizaban la palabra "dueńo», aunque no disponemos de las palabras originales en hasanía. Sea como fuere, la resolución temporal de la oficina fue que los autores del secuestro «vuelvan a los Rguibis lo pagado por ellas y éstos lo hagan así a sus actuales protectores». Finalmente, las mujeres quedaron igualmente en posición de «protegidas» y los secuestradores devolvieron el precio recibido a los intermediarios Erguibat. Estos depositaron el dinero en la oficina española, donde «se haría entrega de las protegidas a sus dueńos; pues no parece natural que nuestros administrados devuelvan las [mujeres] sin resarcirse de lo pagado por ellas» ${ }^{89}$. En definitiva, las cantidades pagadas volvieron a circular en sentido contrario, pero las mujeres continuaron en una posición servil.

La importancia de los sistemas de clasificación social se aprecia en este ejemplo de 1950, en el que un individuo reclamaba que un "negro» que compró su hermano en Adrar se había fugado y pedía que se le buscase, porque a posteriori se enteró que era un liberto. El amo pedía que las autoridades españolas reclamasen la vuelta del antiguo esclavo, que se había pasado a zona francesa, pero las autoridades españolas estimaron que si era una persona libre no podían hacer reclamación alguna, si el huido no había cometido ningún tipo de delito ${ }^{90}$. En otros casos, las paradojas y contradicciones eran mucho más remarcadas. Mahamud, de Suad Ehl Jali Iahia compró en zona francesa a "dos negras, menores de edad», y tras venderlas en la zona española fue detenido y encarcelado. El desenlace del caso indica el poder de los vínculos de patronazgo hacia las esclavizadas, ya que después de que las chicas fuesen declaradas libres, leemos que «una de ellas se casó con el referido MAHAMUD ULD MOHAMMED (Coria) $)^{91}$.

89 Id.

90 Asuntos negros (esclavitud), 10 de mayo de 1950, AGA, 81/14522.

${ }^{91}$ Nota. Vide para el expediente esclavos. Septiembre de 1950, AGA, 81/14522. 


\section{CONCLUSIONES: DESCONCIERTO COLONIAL}

Las escasas instrucciones dictadas sobre la esclavitud en el Sáhara son un indicador del desconcierto al que se vieron abocados los oficiales coloniales sobre el terreno. Las autoridades coloniales consideraban que el comercio de esclavos había sido prohibido y que ya no podía haber compraventa. Pero a pesar de esa supuesta abolición, nada impedía que los esclavos ya existentes mantuviesen su estatus; es decir, que no se pretendía terminar con la existencia de esclavos. Sin embargo, como en el protectorado del norte, las instrucciones también indicaban que era preciso intervenir en los casos de maltrato o cuando los esclavos se presentasen a las oficinas españolas para reclamar su libertad o denunciar su explotación. Más allá de estas intervenciones, el principal objetivo de esta política laxa era sobre todo evitar contravenir a las elites locales que disponían de esclavos o sujetos dependientes, sin alterar los principios religiosos islámicos, que devinieron un asunto sumamente delicado para la política colonial. Esta estrategia política fue muy similar a la adoptada por Francia en aquellos años en la fronteriza Mauritania ${ }^{92}$.

En realidad, la gestión de la esclavitud y el servilismo estuvo marcada por una praxis de improvisaciones. Sin embargo, un doble rasero regía la toma de decisiones: se debía implementar la prohibición de esclavitud, sin generar malestar entre los jefes tribales. Ello provocó también la mala conciencia de algunos oficiales, que compraron esclavas para liberarlas o tomarlas a su servicio. $\mathrm{Y}$ a pesar de esas incertidumbres, la Administración intervino en asuntos importantes como la certificación de manumisiones. Este hecho alteraba incluso los mecanismos cheránicos existentes hasta la fecha y la Administración española adoptaba un rol de juez en estas liberaciones, contraviniendo el propio objetivo de no entrometerse en asuntos religiosos. En cualquier caso, las relaciones serviles y de extrema dependencia no estaban en discusión, sino los abusos y la extralimitación de los amos.

Esta praxis política se conjugó en un espacio de fronteras. Las autoridades españolas y francesas gestionaban esta frontera, tenían formalmente el monopolio sobre ella, pero no podían controlarla. De ahí que esta competencia colonial fuese aprovechada por los bidan en el caso de la esclavitud y especialmente con las transacciones. Pero la frontera también fue manejada por los subalternos. La movilidad espacial fue notable en el caso de algunas mujeres que atravesaron fronteras una y otra vez, buscando familiares, antiguos amos, huyendo o a merced de nuevos patrones. Precisamente la documentación analizada revela la arena de las estrategias locales en este nuevo

92 Pettigrew (2016): 425-426. 
escenario donde el colonialismo no era una mera imposición. Los bidan eran conscientes del papel jugado por las autoridades, como se observa entre quienes se presentaban a las oficinas para evitar ser reprendidos por la compra de esclavos, aduciendo que desconocían la prohibición. Los jefes tribales ejercieron su autoridad también para defender un statu quo gracias al cual disponían en sus campamentos de jaimas compuestas por pastores, domésticas y personas dedicadas a otras labores serviles que, a pesar de su carácter subordinado, formaban parte de su unidad doméstica y de su grupo de parentesco y proximidad. Estos actores subordinados también hicieron oír su voz en este escenario, como en el caso de los que huían de sus patrones, o aquellas que dedicaron todos sus esfuerzos a liberar a su descendencia, como Mbarka. Estas personas ejercieron su agencia para escapar de la violencia y los abusos de sus amos. Pero tampoco se debe olvidar que esta agencia estaba conformada y restringida por normas y prácticas hegemónicas en la sociedad local.

El lenguaje dado por descontado en los documentos, como expresión de poder, tuvo sus efectos políticos, aunque también era el reflejo de incertidumbres. Por un lado, palabras como esclavo, liberto, protegido, podían dirimir el destino de las personas, y tenían un poder performativo, según como se etiquetara a la persona y se definiera su estatus jurídico. Por otro lado, existía una incertidumbre para interpretar el propio fenómeno, con su débil frontera entre el patronazgo, el servilismo y el parentesco, que continuó después de 1958, como demuestran las ambiguas categorías manejadas en el censo de 1974, hasta la progresiva transformación de la sociedad saharaui a raíz del exilio y el conflicto armado. Se supone que estas desigualdades estatutarias fueron revocadas por la nueva República Árabe Saharaui Democrática a partir de 1976, o por la Constitución marroquí de 1962, en los territorios controlados por Marruecos. Sin embargo, la polémica desatada por el documental Stolen (2009) sobre la supuesta persistencia de la esclavitud en los campos de refugiados de Tinduf mostró el grado de politización que esta cuestión continúa arrastrando en la zona y ponía sobre la mesa un reto para la historia y las ciencias sociales ${ }^{93}$, que he tratado de responder en este trabajo a partir de materiales de la época colonial: ‘̇a qué esclavitud se referían los autores del documental y a qué se referían los detractores de aquel para negar su existencia? ¿Se trataba de esclavitud, de servilismo o de clientelismo? Para replicar al primer documental, el hispanovenezolano Carlos González realizó otro documental titulado Robbed of Truth (2011), en el que reconstruía la historia de Fetim Salam, que en el primer film era presentada

93 Para un resumen de la polémica, véase De Dalmases (2012): 166-174. Haidar (2014) ha documentado la mala fe de las traducciones del hasanía al inglés en los testimonios orales de aquel documental. 
como «esclava de una blanca», y en el segundo como «hija adoptiva». Estas confusiones terminológicas nos recuerdan el desconcierto relatado en este trabajo. Por un lado, el peso de nociones unívocas de esclavitud ha dificultado comprehender la existencia de vínculos sociales basados en la dependencia y el servilismo que no pasan siempre por la compraventa o el color de la piel ${ }^{94}$. Por otro, las trampas al solitario realizadas en documentales como Stolen, que confunden negritud con esclavitud (o ser blanco con ser libre), como en la época colonial, tampoco pueden esconder la persistencia de desigualdades basadas en el origen servil o el color de la piel, que ya están siendo discutidas y criticadas por los propios afectados ${ }^{95}$.

\section{Bibliografía}

Angosto Fernández, L. F. y Kradolfer, S. (eds.) (2012). Everlasting Countdowns: Race, Ethnicity and National Censuses in Latin American States. Newcastle upon Tyne: Cambridge Scholars Publishing.

Balandier, G. (1951). La situation coloniale: approche théorique. Cahiers Internationaux de Sociologie, 11, 44-79.

Bengoechea Tirado, E. (2016). Políticas imperiales y género. La Sección Femenina en la provincia de Sáhara (1961-1975) [tesis doctoral]. Universitat de València. Disponible en: https://www.educacion.gob.es/teseo/imprimirFicheroTesis.do.

Blanco González, M. C. (2019). Emancipación en el Sáhara Occidental: Activismo reivindicativo de mujeres y afrosaharauis. Eikasia. Revista de Filosofía, 87, 257-310.

Boëtsch, G. y Ferrié, J. N. (2000). De la modernité paradoxale du point de vue de l'anthropologie physique sur les groupes serviles au Sáhara. En M. Villasante-de-Beauvais (dir.). Groupes serviles au Sahara. Approche comparative à partir du cas des arabophones de Mauritanie (pp. 269-276). París: CNRS.

Botte, R. (2007). Liberté formelle et dépendances idéologiques en Afrique. Comment déconstruire les relations maîtres/esclaves? Les Cahiers du Centre de Recherches Historiques. Archives, 40, 163-183. Disponible en: https://doi.org/10.4000/ccrh.3396.

(2010). Esclavages et abolitions en terres d'Islam. Bruxelles: André Versaille.

Caratini, S. (1989). Les Rgaybāt (1610-1934). París: Éditions L’Harmattan.

Caro Baroja, J. (1990) [1955]. Estudios saharianos. Madrid: Júcar Universidad.

Chebel, M. (2007). L'esclavage en terre d'Islam. París: Fayard.

Cheikh, A. W. O. (1993). L'évolution de l'esclavage dans la société maure. En E. Bernus, P. Boilley, J. Clauzel, J. L. Triaud. Nomades et commandants. Administration et sociétés nomades dans l'ancienne AOF (pp. 181-192). París: Karthala.

94 Valensi (1986) y Villasante-de-Beauvais (2000a).

95 Blanco González (2019). 
Comaroff, J. y Comaroff, J. (1992). Ethnography and the Historical Imagination. Boulder: Westview Press.

De Dalmases, P. I. (2012). La esclavitud en el Sáhara Occidental. Barcelona: Ediciones Carena.

(2014). El Sáhara Occidental en la bibliografía española y el discurso colonial [tesis doctoral]. Universitat Autònoma de Barcelona. Disponible en: https://ddd.uab.cat/ pub/tesis/2014/hdl_10803_131287/pidolde1.pdf.

Ennaji, M. (1994). Soldats, domestiques et concubines. L'esclavage au Maroc au XIXe siècle. Casablanca: Editions Eddif.

Ensel, R. (1998). Saints and Servants. Hierarchical Interdependence between Shurfa and Haratin in the Moroccan Deep South. Amsterdam: Universiteit van Amsterdam.

González, I. G. (2007). La hermandad hispano-árabe en la política cultural del franquismo, 1936-1956. Anales de Historia Contemporánea, 23, 183-198.

Goode, J. (2009). Impurity of blood. Defining race in Spain, 1870-1930. Baton Rouge: Louisiana State University Press.

Haidar, L. (2014). La esclavitud en el documental «Stolen» ¿Esclavitud traducida o traducción esclavizada? En A. Martín Casares (ed.). Esclavitudes hispánicas (siglos XV al XXI): horizontes socioculturales (pp. 283-298). Granada: Editorial Universidad de Granada.

Harrison, C. (2003). France and Islam in West Africa, 1860-1960. Cambridge: Cambridge University Press.

Hernández Ciro, E. (2016). Microhistoria italiana, antropología y archivos judiciales. Historia y Sociedad, 30, 75-104. Disponible en: https://doi.org/10.15446/hys. n30.52479.

Keesing, R. M. (1987). Anthropology as interpretative quest. Current Anthropology, 28 (2), 161-176. Disponible en: https://doi.org/10.1086/203508.

Lewis, B. (1990). Race and Slavery in the Middle East. An Historical Enquiry. New York; Oxford: Oxford University Press.

López Bargados, A. (2000). "Ces orgueilleux seigneurs du désert saharien». Images coloniales et postcoloniales des sahraouis en Espagne. Annuaire de l'Afrique du Nord, 39, 363-377.

- (2001). «Ni blanco ni negro, sino gris». Los proyectos emancipatorios del colectivo harratin en la sociedad mauritana contemporánea. En M. Nash y D. Marre (eds.). Multiculturalismos y género. Un estudio interdisciplinar (pp. 195-218). Barcelona: Edicions Bellaterra.

- (2003). Arenas coloniales. Los Awlâd Dalìm ante la colonización franco-española del Sáhara. Barcelona: Edicions Bellaterra.

Martín Corrales, E. (2013). Tensiones judeo-musulmanas en el protectorado espańol en Marruecos en tiempos de la II República (1931-1936). En E. Martín Corrales y M. Ojeda Mata (eds.). Judios entre Europa y el norte de África (siglos XV-XXI) (pp. 93-117). Barcelona: Edicions Bellaterra.

Martínez Milán, J. (2000). El colonialismo español en el Sáhara Occidental y en la zona sur del Protectorado español en Marruecos, 1885-1945 [tesis doctoral inédita]. Universidad Nacional de Educación a Distancia. 
Mateo Dieste, J. L. (2014). Imágenes y ambivalencias de la política española hacia la esclavitud en Marruecos (1880-1930). Historia y Politica, 31, 255-280.

Mcdougall, E. A. (2000). Un monde sens dessus dessous: Esclaves et affranchis dans l'Adrâr mauritanien, 1910-1950, en M. Villasante-de-Beauvais (dir.). Groupes serviles au Sahara. Approche comparative à partir du cas des arabophones de Mauritanie (pp. 121-143). París: CNRS.

Nerín, G. y Bosch, A. (2001). El imperio que nunca existió: la aventura colonial discutida en Hendaya. Barcelona: Plaza \& Janés.

Ortiz García, C. (2006). Andanzas africanas de Julio Caro Baroja. Revista de Historiografía, 4, 153-168.

Pascon, P. (1984). La maison d'Illigh et l'histoire sociale du Tazerwalt. Rabat: Smer.

Pettigrew, E. (2016). The Heart of the Matter: Interpreting Bloodsucking Accusations in Mauritania. The Journal of African History, 57 (3), 417-435. Disponible en: https://doi. org/10.1017/S0021853716000323.

Seddon, D. (2000). Unfinished business: Slavery in Saharan Africa. Slavery and Abolition: A Journal of Slave and Post-Slave Studies, 21 (2), 208-236. Disponible en: https://doi. org/10.1080/01440390008575313.

Stoler, A. L. (2010). Along the Archival Grain. Epistemic Anxieties and Colonial Common Sense. Princeton, Oxford: Princeton University Press.

Toledano, E. R. (1993). Shemsigul: A Circassian Slave in Mid-Nineteenth-Century Cairo. En E. Burke III. Struggle and survival in the modern Middle East (pp. 59-74). London; New York: I. B. Tauris.

(2007). As if Silent and Absent. Bonds of enslavement in the islamic Middle East. New Haven; London: Yale University Press.

Valensi, L. (1986). La tour de babel: Groupes et relations ethniques au Moyen-Orient et en Afrique du Nord. Annales ESC, 4, 817-838. Disponible en: https://doi.org/10.3406/ ahess.1986.283314.

Vergès, F. (2001). Abolir l'esclavage: une utopie coloniale. Les ambigüités d'une politique humanitaire. París: Albin Michel.

Villasante-de-Beauvais, M. (ed.) (2000a). Groupes serviles au Sáhara. Approche comparative à partir du cas des arabophones de Mauritania. París: CNRS Editions.

- (2000b). La question des hiérarchies sociales et des groupes serviles chez les bidân de Mauritanie. En M. Villasante (ed.). Groupes serviles au Sahara. Approche comparative à partir du cas des arabophones de Mauritania (pp. 277-322). París: CNRS Editions.

- (2007). Quelques réflexions sur le devenir des catégories coloniales de classement collectif: races, tribus et ethnies. En M. Villasante-de-Beauvais (dir.). Colonisations et héritages actuels au Sahara et au Sahel: problèmes conceptuels, état des lieux et nouvelles perspectives de recherche (XVIIIe-XXe siècles) (pp. 67-131). París: L'Harmattan.

Wright, J. (2007). The Trans-Saharan Slave Trade. London; New York: Routledge. Disponible en: https://doi.org/10.4324/9780203962817.

Zilfi, M. C. (2010). Women and Slavery in the Late Ottoman Empire. Cambridge: Cambridge University Press. 